\title{
LEBANON'S 2018 ELECTION:
}

\section{New Measures and the Resilience of the Status Quo

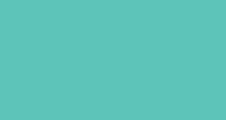

Daniel L. Tavana and Christiana Parreira 


\section{Team}

Daniel L. Tavana \& Christiana Parreira, Authors Mia BouKhaled, Programme Officer Amreesha Jagarnathsigh, Research \& Project Officer Léa Yammine, Deputy Director, Publications Dr. Marie-Noëlle AbiYaghi, Director Nayla Yehia, Design \& Layout

This brief is published in partnership with HIVOS through the Women Empowered for Leadership (WE4L) programme, funded by the Netherlands Foreign Ministry FLOW fund.

The views expressed in this publication are solely those of the author(s) and do not necessarily reflect the views of Lebanon Support nor its partners.

Lebanon Support @ , Beirut, June 2019

No part of this publication may be reproduced, distributed or transmitted in any form or by any means, including photocopying or recording, or other electronic or mechanical methods, without the prior written permission of the publisher, except in the case of brief quotations and referencing in critical reviews and articles, and other noncommercial uses permitted by copyright law. 


\section{LEBANON'S 2018 ELECTION:}

\section{New Measures and the Resilience of the Status Quo

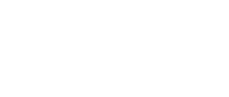

Daniel L. Tavana and Christiana Parreira 


\section{BACK-}

GROUND

On May 6, 2018, nearly two million Lebanese citizens participated in the country's third legislative election since the withdrawal of Syrian forces in April 2005. Before last year, the most recent legislative election was held in 2009. Since then, the Lebanese government has postponed national elections three times, nominally because of the ongoing war in Syria and domestic security concerns related to the outbreak of localised communal conflict in 2011. In June 2017, the government and the parliament resolved this

1

Supporters and opponents of the Syrian government engaged in sporadic conflict in Tripoli, Beirut, Saida, and elsewhere from 2011 to 2014. The onset of the Syrian civil war heightened sectarian tensions, resulting in kidnappings, assassinations, and acts of intercommunal violence during this period. protracted political stalemate by announcing the approval of a new electoral law and scheduling the election.

The repeated postponement of elections heightened a general sense of paralysis in state-society relations that has been building for over two decades. Punctuated by a presidential vacuum that ended only in October 2016, public disillusion with the entrapments of the status quo has grown in recent years. Increasingly, Lebanese citizens have singled out central state institutions as ineffective, unrepresentative, and captured by a collusive political-financial elite class. Public frustration has been compounded both by a refugee crisis due to war in neighboring Syria, as well as a deteriorating economy and looming debt crisis. Increasingly, these frustrations have amplified voices critical of Lebanon's precarity, particularly activists and associational leaders who comprise the civil society sector.

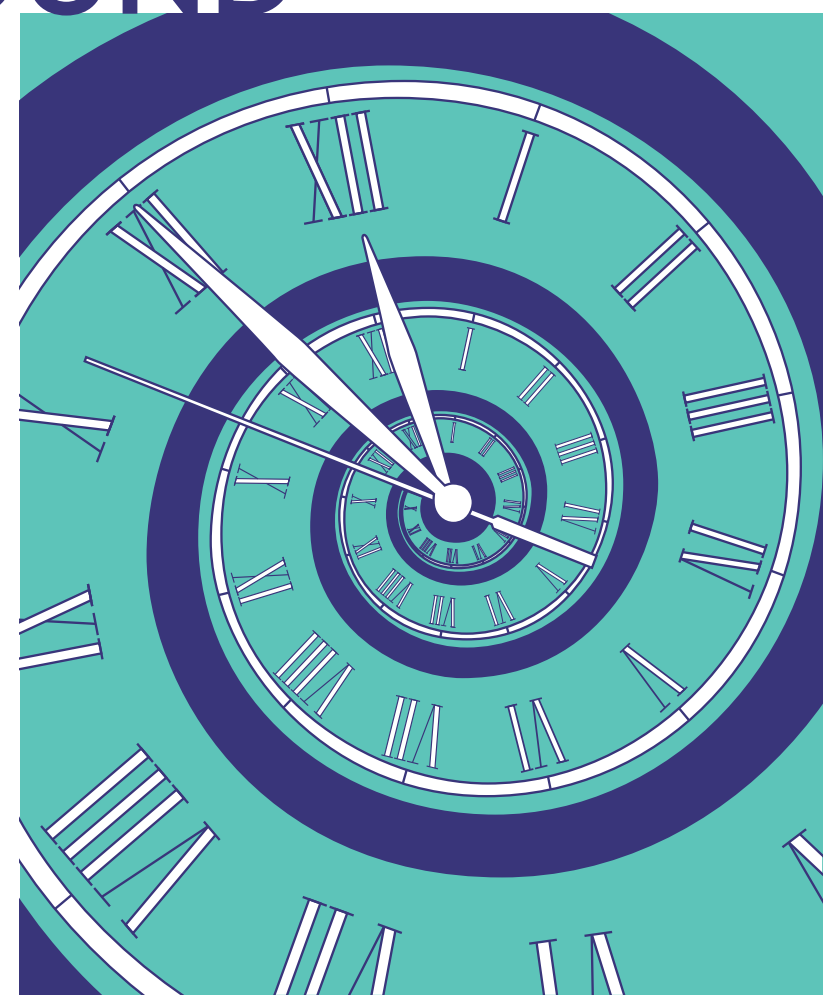

These tensions eventually led party leaders to conclude that a further extension of the legislature's mandate was infeasible. Less than a year after the parliament elected Michel Aoun to serve as President, the country's leading political parties agreed on a new electoral law and a timetable for elections. The new law signaled both change and continuity in a variety of different ways:

/ Lebanon's 26 electoral districts were consolidated into 15 major districts. Beirut's three districts were consolidated into two districts. Minor districts Jbeil and Keserwan were combined into one district, as were the following: Aley and Chouf; Minnieh-Dennieh and Tripoli; Batroun, Bcharre, Koura, and Zgharta; Saida and Jezzine; Tyre and Zahrani; and Bint Jbeil, Marjeyoun-Hasbaya, and Nabatieh. In major districts with more than one minor district, seats were allocated to these minor districts in rough proportion to their population. 
/ 128 seats were allocated to 11 different confessions. The confessional distribution of these seats was not changed: 27 Sunni, 27 Shia, 8 Druze, 2 Alawites, 34 Maronite Christians, 14 Greek Orthodox Christians, 8 Greek Catholic (Melkite) Christians, 5 Armenian Orthodox Christians, 1 Armenian Catholic Christian, 1 Evangelical Christian, and 1 "minority" Christian.

\section{/ A new proportional system replaced the} traditional block vote plurality system. Candidates registered as individuals before forming lists with other candidates in order to be placed on the ballot. After the election, seats were proportionally allocated to lists that met an electoral threshold, calculated as the sum of valid votes and blank ballots divided by the number of seats in the district. Seats were then proportionally allocated to candidates on lists that reached the electoral threshold, according to their confessional denomination and minor district.

/ Eligibility requirements did not change. The minimum voting age was kept at 21 years, and all citizens were automatically registered. Citizens were not assigned to polling stations in the districts in which they live. They were instead assigned to districts according to their family's ancestral residence.

At first glance, this confluence of factors-a nearly decade-long interlude between elections, the uncertainty of a new electoral law, and a recent groundswell in popular outrage against the government-could have provided new actors a rare opportunity to mobilise public disillusion in service of electoral change. Indeed, many of these new actors registered as candidates and formed new, "civil" lists drawing from a variety of different civil society associations and movements. The ascendance of these new actors was complemented by increasing frustration with barriers to women's participation in elections and representation in political life.
Yet, exceptionally high levels of dissatisfaction with electoral institutions and government performance did not result in a meaningful change to the status quo. New lists gained some traction by translating preexisting "civil society" movements into electoral protoorganisations-an important first step that should not be overlooked. Still, these lists failed to present a viable governing alternative to the status quo (much less capture the interest and imagination of ordinary citizens). Nationally, only one seat was won by an independent civil society list, in Beirut I. More surprisingly, 48 of the 74 incumbents who contested seats were reelected (65 percent). Women comprise only 6 out of 128 members, despite the fact that 86 women registered to run (from among 597 candidates). Relatively low turnout (just less than 50 percent of registered voters) contributed to the absence of electoral turnover ("Final Parliamentary Election Results"

NEW LISTS GAINED SOME TRACTION BY TRANSLATING PREEXISTING “CIVIL SOCIETY" MOVEMENTS INTO ELECTORAL PROTOORGANISATIONS-AN IMPORTANT FIRST STEP THAT SHOULD NOT BE OVERLOOKED. STILL, THESE LISTS FAILED TO PRESENT A VIABLE GOVERNING ALTERNATIVE TO THE STATUS QUO (MUCH LESS CAPTURE THE INTEREST AND IMAGINATION OF ORDINARY CITIZENS). 
2018). Uneven, incoherent coalitions of national parties across most electoral districts were also a mitigating factor.

The remainder of this brief will explore howdespite widespread citizen frustration-this status quo prevailed. The brief will subject the above paradoxes to greater empirical scrutiny, with particular attention to the performance of new actors. We draw our findings from an analysis of election results, participant observation of the campaign period, and focus group interviews conducted before and after the election. ${ }^{2}$ This brief will analyse how citizen perceptions of the new electoral law, the entrance of civil society lists and movements, party resource advantages, and extra-legal modes of manipulation contributed to the reproduction of Lebanon's electoral status quo.

\section{THE ELECTORAL LAW AND}

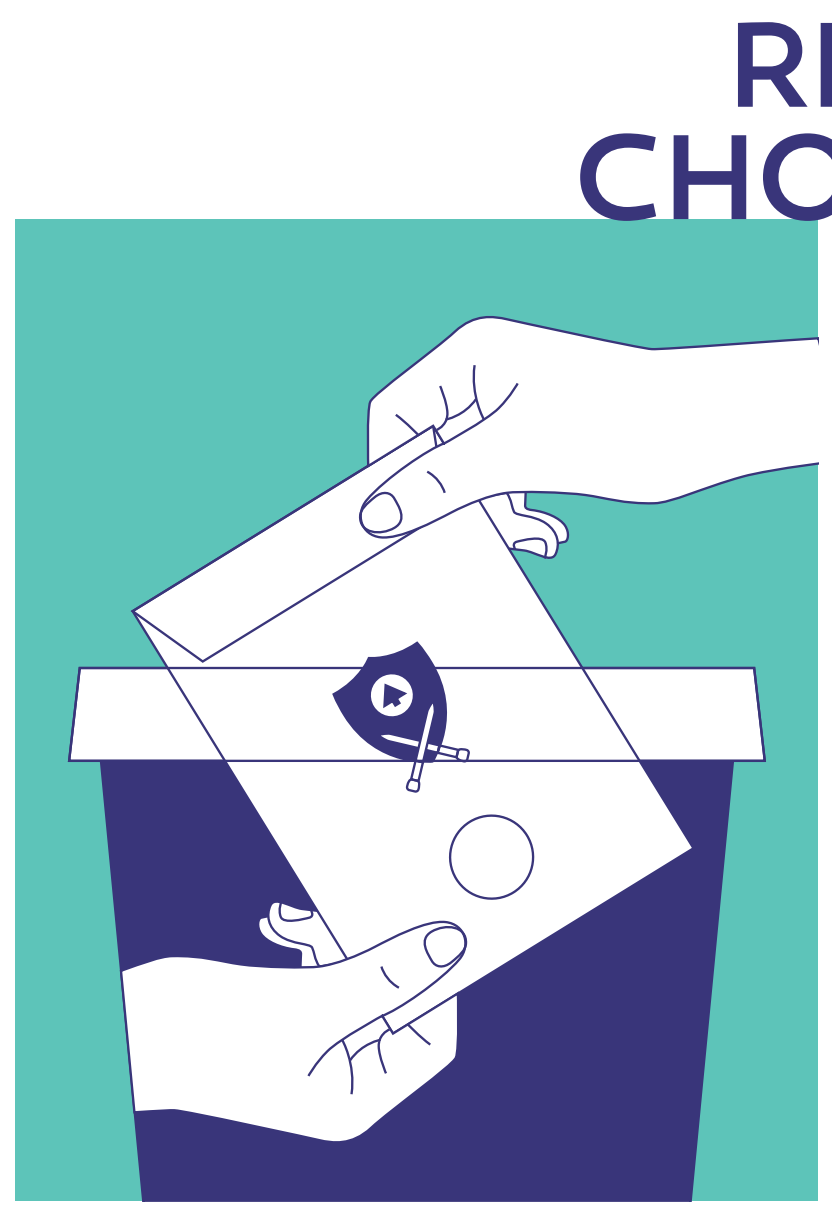

The new electoral law was initially applauded by some as a more pluralistic alternative to the block vote system. This was due not only to the seemingly proportional logic of the electoral formula, but also to the adoption of a uniform ballot that could limit the ability of parties to count votes and monitor citizens' preferences. In practice, however, the new lawparticularly the preferential vote-personalised aspects of the campaign by pushing voters to support only a single candidate even if they did not like other candidates on the list or what the list represented. The law limited voters' ability to choose from among candidates belonging to different lists. This encouraged different, competing parties to run on lists together in an effort to raise the electoral threshold in each district through partisan collusion. 


\section{IN DISCUSSIONS CONCERNING PERCEPTIONS OF THE LAW'S EFFECT ON LOW VOTER TURNOUT, MANY PARTICIPANTS REPORTED A LOSS OF FAITH IN THE ABILITY OF THE SYSTEM TO ENGENDER PROGRESSIVE CHANGE.}

In pre-election focus groups, citizens demonstrated familiarity with the new law, the process of voting, and the new, personalised dynamics encouraged by the preferential vote. It was not uncommon for participants to use language found in the law itself, such as "lists" and "electoral thresholds." Many participants had also seen samples of pre-printed ballots circulated by local party agents and media organisations, allowing them to demonstrate a familiarity with the trade-offs encouraged by the new list and preferential vote systems. This finding runs counter to a common narrative advanced by many independent civil society candidates, namely, that the new law was confusing and too difficult to understand.

Citizen perceptions seemed to change after the election. In post-election focus group interviews, some citizens expressed faith in the system's fair distribution of seats to parties according to their electoral strength. Others lauded the election as an opportunity to "prove ourselves: it is our dignity in question." However, most citizens expressed frustration with constraints to their freedom to choose. Because parties formed lists with different parties across districts, voters could discern manipulations of the electoral threshold. In Baabda, a list formed with representatives of Amal Movement and the Free Patriotic Movement (FPM) led one participant to observe that "...we were fooled, like [the parties] are taunting us, only to do what serves their own interests." One participant observed that these local agreements came at the expense of more meaningful political programs. In this respect, lists were perceived by many as collusive agreements that limited voters' freedom to choose.

In discussions concerning perceptions of the law's effect on low voter turnout, many participants reported a loss of faith in the ability of the system to engender progressive change. Others noted that their peers felt excluded, often because members of each list were selected by parties without citizen input. Citizens expressed disappointment in the law's seeming encouragement of clientelism, whereby the preferential vote bound citizens to a prominent local elite through personal voting. In some cases, voters used heuristics derived from previous electoral experiences to choose from among the different packages of material incentives candidates had to offer. 


\section{SKEPTICISM TOWARDS}

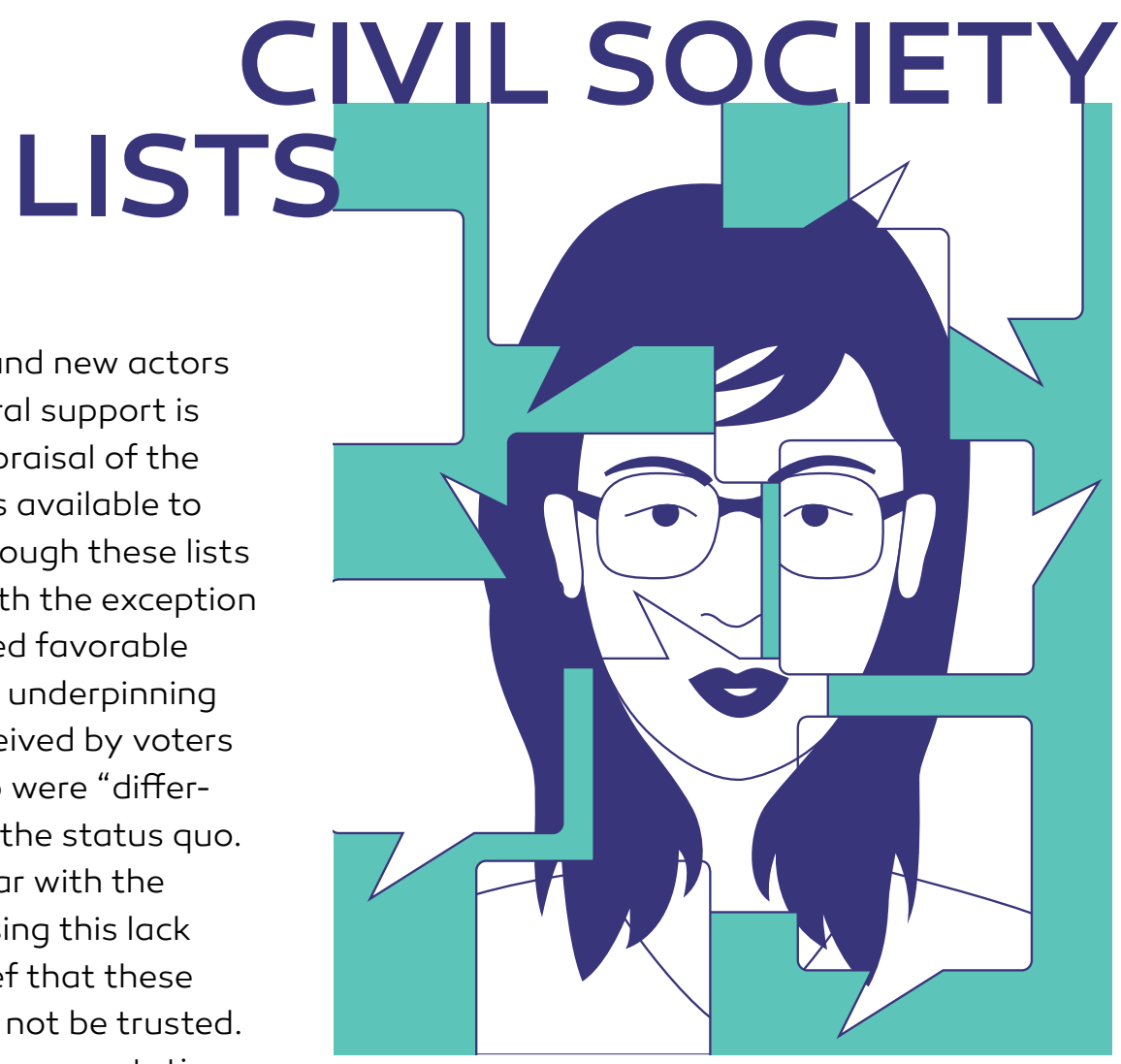

The failure of civil society lists, and new actors more broadly, to capture electoral support is best understood through an appraisal of the contextually-dependent options available to voters in different districts. Although these lists failed to secure a single seat (with the exception of Beirut I), citizens still expressed favorable assessments of the movements underpinning them: these new lists were perceived by voters as collections of individuals who were "different" and interested in changing the status quo. However, voters were not familiar with the members of these lists, often using this lack of familiarity to signal their belief that these lists could not succeed, or could not be trusted. This generalised lack of trust in representative institutions has led many citizens to express skepticism towards these lists. Focus group participants framed this skepticism as a product of the system itself, often reporting that these new lists were too "clean" or "naïve," and that national elites would never actually allow them to implement the changes they proposed. This sort of tactical voting-itself a product of the new electoral law-may have depressed turnout and public support for these lists.

When participants were asked to describe the characteristics of their ideal candidates, they often mimicked language used by new candidates running on civil society lists. Participants expressed support for candidates offering a "national renewal," or a new social contract built on needs and rights. Despite these signals, voters still expressed strong preferences for candidates who were from their sect, belonged to a national political party representing that sect, or both. When asked about the tension between the attributes they

sought in a candidate and those they actually supported, participants often deflected blame for corruption and poor services to rival parties from outside their sect. In contexts where elite predation and government inefficacy are widespread, such behavior is quite common (De Vries and Solaz 2017). Voters channeled this blame into support for providing their favored candidate with an electoral mandate. This was often the case among those who expressed support for the Lebanese Forces (LF) or FPM: participants were reluctantly satisfied with leaders of the party, such as ministers, often claiming that party rivals were acting as obstructionists. Similarly, in Tripoli, voters were willing to support mainstream political parties because they felt as if these parties deserved a "second chance." In general, it appears that the universality of disappointing performance among major parties, along with a lack of alternative candidates with a proven track record, led voters to revert to status quo options. 
Countervailing pressures to support both national political parties and a reformist approach to issues of corruption and poor governance may be in part due to national parties' ability to coopt the language of reform. Recent survey data suggests that corruption and poor governance are among the top concerns of Lebanese citizens ("Lebanon Poll Results" 2018; "Lebanon Economic Vision" 2018). Parties capitalised on these frustrations by nominating new candidates from within their ranks. Participants often expressed a reluctance to vote for candidates from outside their sect, even if they were frustrated with the party claiming to

\section{IN GENERAL, IT APPEARS THAT THE UNIVERSALITY OF DISAPPOINTING PERFORMANCE AMONG} MAJOR PARTIES, ALONG WITH A LACK OF ALTERNATIVE CANDIDATES WITH A PROVEN TRACK RECORD, LED VOTERS TO REVERT TO STATUS QUO OPTIONS.

represent that sect in the district. Parties were able to effectively amplify the voices of their newer candidates in order to capture voters who might have otherwise voted for a civil society list. These observations complicate widely-shared critiques of new actors. It is not necessarily the case that reformist rhetoric is detached from the everyday hardships of
Lebanese voters. Rather, it may be the case that status-quo parties and incumbents were better able than new actors to manipulate this rhetoric for electoral purposes.

In Beirut I, for example, the Future Movement's "The Future is for Beirut" list comprised 11 individuals, 5 of whom were previous MPs. The list received over 60,000 votes: over 20,000 of those preferential votes went to Saad Hariri, but over 21,000 preferential votes went to the 6 non-incumbents, such as Rola Al-Tabash and Rabea Hassouna. Similarly, in South II, the "Hope and Loyalty" list backed by Hezbollah and Amal comprised 7 individuals, 5 of whom were previous MPs. The list won all 7 seats in the district, though the two non-incumbents (Inaya Eizzidine and Hussein Jechi) performed particularly well, winning over 42,000 preferential votes out of the 134,000 total list votes. Participants occasionally referenced internal changes to party candidates, praising these efforts as attempts to improve their preferred party's image among supporters. Many frustrated voters were willing to overlook their preferred party's ideologically incoherent-but strategic-alliances with other parties in exchange for some clientelist reward. But mainstream parties were also able to channel this frustration by adopting a discourse of reform that was amplified by the incorporation of new candidates into these parties. The image of a reforming party able to provide voters with a clear patron and material resources stands in contrast to the absence of a coherent message or alternative proposed by civil society lists. Independent, civil society lists were frequently criticised for failing to develop clear programs and failing to articulate solutions to problems perceived as core to the reformist agenda, such as the personal status law. On the whole, these lists were torn between wanting to maintain a united front, on one hand, and developing a clear ideological platform (that might alienate would-be supporters) on the other. 


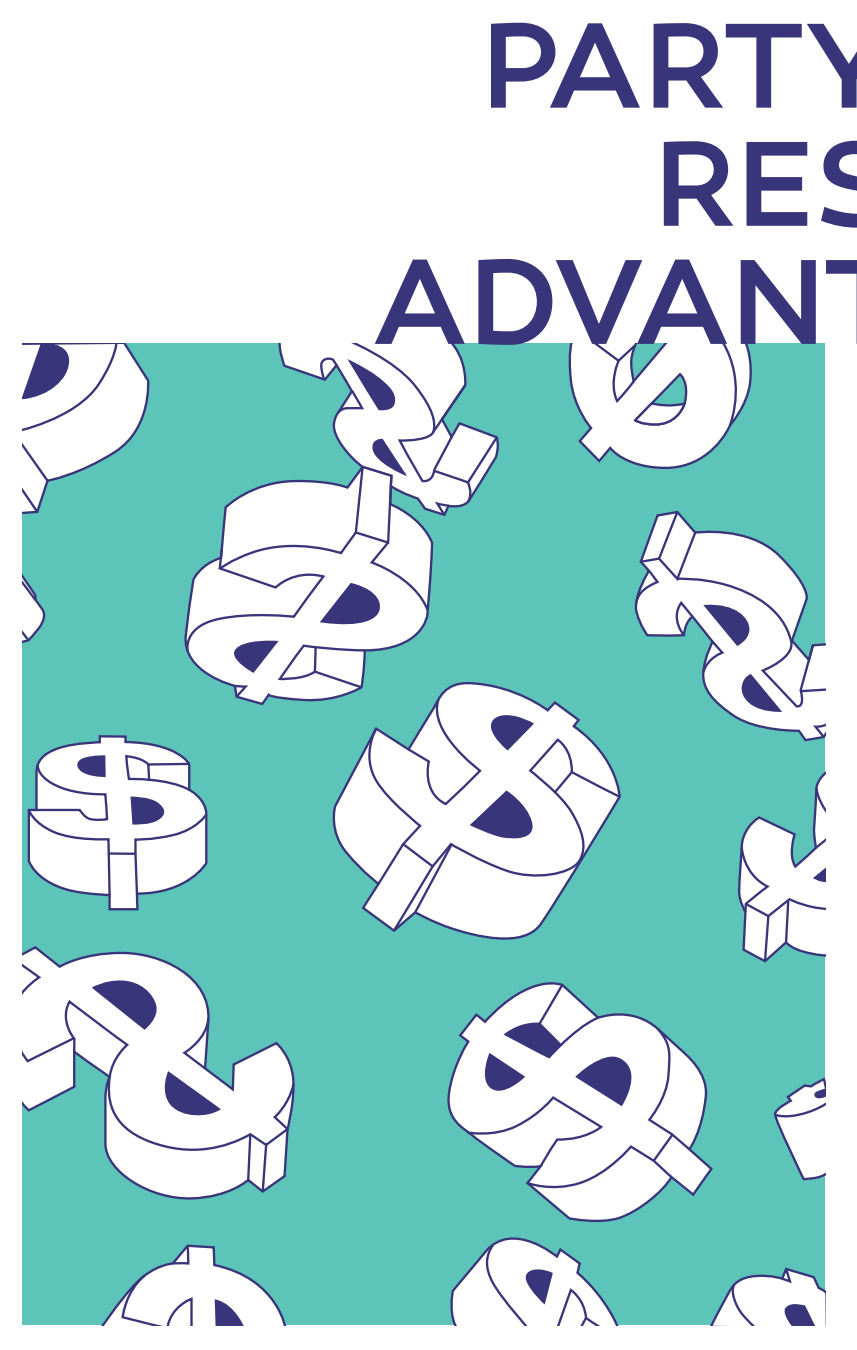

Established national parties enjoy disparate access to a number of resource advantages relative to political newcomers and independents. The excessively high cost of television, radio, print, and other advertising content often price candidates without backing from a well-funded party out of competition altogether. Television interviews were estimated to cost candidates an estimated USD 150,000 to 250,000, and radio interviews between USD 2,000 and 3,000, depending on length and station. These costs often increase as election day draws closer. Several media outlets were said to offer advertising packages to lists priced at upwards of USD 1.5 million. Billboardsone of the most ubiquitous modes of campaign advertisement in Lebanon-can cost anywhere between USD 1,000 and 3,000 per day ("Lebanon parliamentary candidates" 2018).

The benefits of this pay-to-play system are magnified by the fact that most major media outlets are affiliated with, and often financially supported by, one or more political factions. Some observers reported that various media outlets did not correctly label campaign advertisements, a clear violation of the law. This is surprising, given that the new electoral law outlined a number of new media regulations candidates, lists, and parties were obligated to observe and empowered the Supervisory Committee for Elections (SCE) to impose fines and other penalties for misconduct. Unfortunately, many of these regulations were not adequately communicated to several key stakeholders, including candidates, parties, and public and private media organisations. The SECE did not have the capacity to enforce these regulations or investigate or sanction even the most obvious violations.

Another key resource advantage parties maintain is the ability to provide a variety of services to constituents on a conditional basis, in exchange for political support, by virtue of their political privileges within the state. Parties often cultivate local brokerage networks to form long-term relationships with constituents, who they reward with more or less costly goods that can be withdrawn if the client does not continue to provide electoral support. They may also engage in vote-buying, an alternate strategy in which cash is directly exchanged for votes, with or without a history of interaction between broker and client (Scott 1972; Stokes et al. 2013). Focus group participants identified a long record of this type of service provision as a particularly salient feature of candidates they considered supporting. Where this track 
record was not readily available, participants used other heuristics, such as the candidate's wealth and campaign content. Though participants remarked that these services would ideally be provided by the state, they also expressed skepticism towards the state's capacity to do so in an equitable and efficient way. Moreover, they observed the prevalence of clientelist transactions in their communities, noting that principled rejection of this type of service provision would leave them at a disadvantage for no real reason.

These sentiments provide evidence of a dynamic in which mainstream parties' penchant for clientelist service provision, coupled with poor-quality public services, perpetuates a system in which voters willingly become accountable to their political representatives, even with full knowledge of how this system produces inefficient, wasteful outcomes (Magaloni 2008). ${ }^{3}$ Participants also noted that, should they choose to break clientelist ties and vote against their former patrons, parties can deploy a variety of punishment mechanisms, including withdrawal of key services. The ubiquity of these resource advantages also confer a wide variety of symbolic benefits to parties and incumbents. Without access to these resources, new actors struggled to convince voters that a vote of conscience would ultimately deliver similar or better economic benefits.

In accordance with these observations, when focus group participants were asked to describe the types of services they have received in the past, or would like to receive in the future, they often described welfare goods typically associated with state provision. Participants cite education expenses, medical care, and stable employment opportunities as the types of services for which they turn to political representatives for assistance. One participant in Metn, for example, stated: "I will vote for Elias Bou Saab. He is a good man, with a lot of connections, and my son should be entering the university soon, so I can tell him that I voted for him and he can support my son's tuition fees." Of course, comparatively higher levels of stigma associated with naked vote-buying, as opposed to clientelist service provision, may mean that participants were less comfortable disclosing more directly fungible patronage. In many cases, however, participants drew a direct link between the paucity of public, unconditional services and their willingness to participate in clientelist transactions, suggesting that voters understand political patronage as a way to recover the high costs of a poorly functioning state.

Mainstream political parties in Lebanon maintain disproportionate access to resources leveraged in clientelist transactions for two key reasons. First, representation within the state bureaucracy affords the incumbent elite class the ability to disperse public employment positions and state funding strategically to supporters. Second, several of the largest parties have access to private funds, foreign government funds, or both that provide them with additional resources.

\section{THE HIGH PREVALENCE OF CLIENTELISM IN THE} LEBANESE CONTEXT, HOWEVER, DOES NOT ONLY ADVANTAGE INCUMBENT PARTIES AND ELITES. EVEN WHEN IT COMES TO POLITICAL NEWCOMERS, THESE ADVANTAGES REINFORCE THE PRIMACY OF CANDIDATES WITH PRE-EXISTING SOURCES OF WEALTH. 
Prior research indicates that parties engage in clientelist transfers primarily among core voters in certain areas, and swing constituents in others, depending on their ability to monitor voter behavior and longer-term party goals (Cammett 2014; Corstange 2012). The high prevalence of clientelism in the Lebanese context, however, does not only advantage incumbent parties and elites. Even when it comes to political newcomers, these advantages reinforce the primacy of candidates with pre-existing sources of wealth. Winning candidates such as Najib Mikati, Fouad
Makhzoumi, and Nehme Efrem-the first two of whom are not affiliated with a national party-are among the wealthiest individuals in Lebanon. This wealth is perceived by voters as an advantage relative to political independents who lack this financial clout. For newcomers without a proven track record, status as a business magnate lends itself to the perception that these candidates will be able to act as traditional zu'ama, capriciously distributing social assistance to those who promise electoral support.

\section{ELECTORAL \\ When party resources were not able to guar- antee electoral success, parties and candi- dates often violated the electoral law through the selective use of extra-legal mechanisms of manipulation. Beyond the buying and selling of votes in exchange for services, according to the Lebanese Association for Democratic Elections (LADE), these viola- tions included attempts to use public places, places of worship, and schools for electoral activities; campaigning during the period of electoral silence; and the intimidation and threat of violence on the part of candidates. Following the election, LADE reported over 7,000 of these and other violations ("Initial Report" 2018).}

EXTRA-LEGAL MANIPULATION

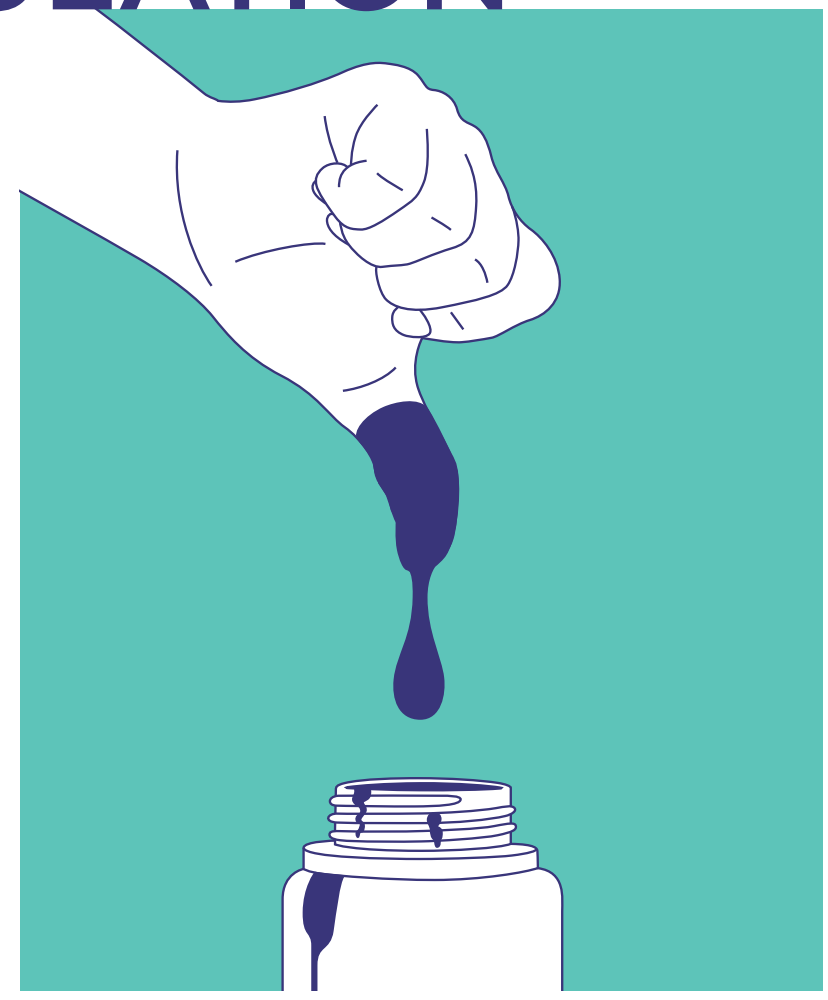


In most cases, violations can be seen as attempts by candidates and local party agents to secure advantages through the harassment and intimidation of both voters and election officials. In Bekaa I (Zahle), for example, small clashes erupted between supporters of the Lebanese Forces and Myriam Skaff's "Popular Bloc" list. During election day, election officials did not respond to reports of violations submitted by candidates from both lists. Eventually, the Lebanese security forces were deployed to the district to ensure tensions did not escalate. In a press conference, Lebanese Forces leader Samir Geagea told supporters that he and the party were proud of them: "They may spend a night in jail, but jail is for men" (Harb et al. 2018). In other cases, manipulation was milder: party agents used electoral rolls to track local turnout and selectively remove election monitors where possible.

Though these violations have been documented by $L A D E$, it is important to note the way parties mobilised a discourse of victimhood to paint their opponents as serial cheaters in order to justify their own violations. Claims that other parties are violating the law feeds into the sectarian rhetoric used by many parties and candidates to encourage members of their own sect or parties to vote. This is not to suggest that violations are insincere or purely a part of the discursive repertoires used by parties and candidates. But the sheer number of violations alleged by parties themselves suggests that these allegations are used as signals to voters that the party or sect is in trouble and in need of assistance. These practices reinforce the idea that the party needs to be defended at the ballot box.

These practices are encouraged by the recruitment of local partisan agents that are able to monitor turnout and coordinate with political parties in real time. In many cases, parties are able to complement the monitoring capacity provided by these agents with pre-electoral information provided by party brokers. On election day, both brokers and agents mobilise voters in machine-like form. Often, when these efforts fail, or when victory is at risk, parties use sectarian rhetoric, promises to expose cheating by rivals, and even the threat of violence to encourage their own supporters to vote. These factors significantly disadvantaged new actors on and before election day.

IN MOST CASES, VIOLATIONS CAN BE SEEN AS ATTEMPTS BY CANDIDATES AND LOCAL PARTY AGENTS TO SECURE ADVANTAGES THROUGH THE HARASSMENT AND INTIMIDATION OF BOTH VOTERS AND ELECTION OFFICIALS. 


\title{
CONCLUSION AND \\ RECOMMENDATIONS
}

\begin{abstract}
Political stability cannot be built indefinitely on undiluted clientelism, partisan collusion, and modest civil alternatives to status quo politics. Elections remain the primary mechanism through which citizens can deliver responsive, accountable governments. In Lebanon, this will require sustained citizen engagement between elections, innovative approaches to governance challenges, and inclusive models of reform.
\end{abstract}

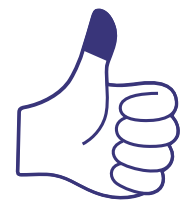

The Lebanese Council of Ministers should agree to an independent review of the new electoral law that prioritises input from Lebanese citizens. This review should assess the extent of citizen satisfaction with and confidence in the electoral process. This review should inform legislative deliberation over whether or not to amend the electoral law (Law No. 44 of 2017). The inclusion of temporary special measures to increase women's representation on lists and in Parliament should be a critical component of this review.

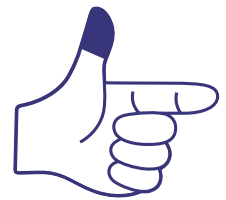

The Lebanese Parliament and Council of Ministers should develop legislation that will strengthen the Supervisory Committee for Elections (SCE).

In subsequent elections, the SCE should be empowered to credibly investigate and sanction violations of campaign and media regulations. Further, the SCE should be obligated to release each candidates' financial reports and the SCE's audits of these reports as part of a more concerted effort to implement campaign finance reform.

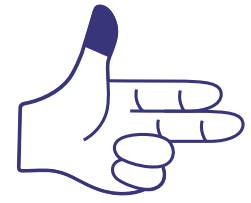

International organisations, foreign governments, and other donors must publicly disclose and assess the impact of their election-related activities and programs. In subsequent elections, these actors must ensure that their work does not advantage specific candidates, parties, or lists, undermine the mandate of the SEC, or strengthen any aspect of the electoral process that does not meet international standards. These organisations must support activities and programs in between elections, particularly those that empower citizen efforts to monitor Parliament's work and encourage citizen engagement in the legislative process.

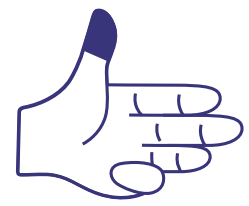

Candidates, parties, and lists should prioritise activities that will allow citizens to engage more meaningfully and regularly with the legislative work of their representatives. Encouraging citizen engagement in legislative work and soliciting citizen input may blunt the clientelist nature of legislative elections. New actors in particular should explore opportunities to sustain citizen interest in national politics through the monitoring of legislative work, the institutionalisation of party structures, and the recruitment of new members from an existing base of volunteers. 


\section{REFERENCES}

Cammett, Melani. Compassionate Communalism: Welfare and Sectarianism in Lebanon. Ithaca; London: Cornell University Press, 2014.

Corstange, Daniel. "Vote Trafficking in Lebanon." International Journal of Middle East Studies 44 no. 3 (2012): 483-505. DOI: https://doi.org/10.1017/SOO20743812000438.

De Vries, Catherine and Hector Solaz. "The Electoral Consequences of Corruption." Annual Review of Political Science 20 (1): 391-408. 2017.

"نتائج الإنتخابات النيابية لعام 2018 [Final Parliamentary Election Results, 2018]. Ministry of Interior and Municipalities, Lebanon. 2018. Accessed July 1, 2018. https://bit.ly/2JS3IRT.

Daniel Hilton et al. "Lebanon: Election Day Sees Intense Rhetoric amid Low Turnout." Middle East Eye. May 6, 2018. Accessed April 1, 2019. https://www.middleeasteye.net/news/ lebanon-election-day-sees-intense-rhetoric-amid-low-turnout.

Lebanese Association for Democratic Elections. تقرير الجمعية الاولي لتقييم يوم الاقتراع:Initial Report Evaluating Election Day]. Beirut: LADE. 2018. 1-10. Accessed April 1, 2019. https://bit.ly/2CMqsHI.

McKinsey \& Company. Lebanon Economic Vision. Beirut: Ministry of Economy. 1-1274. 2018, Accessed April 1, 2019. https://www.economy.gov.lb/media/11893/20181022-1228full-report-en.pdf.

"Lebanon Parliamentary Candidates Charged as much as \$240,000 for Airtime." Al-Arabiya News. April 26, 2018. Accessed April 1, 2019. http://english.alarabiya.net/en/News/middleeast/2018/04/26/Lebanon-elections-6-000-for-a-minute-talk-show-can-cost-240-000.html.

National Democratic Institute. Lebanon Poll Results Following May 7 Parliamentary Elections. June 22, 2018. Accessed April 1, 2019. https://www.ndi.org/publications/ lebanon-poll-results-following-may-7-parliamentary-elections.

Magaloni, Beatriz. "Credible Power-Sharing and the Longevity of Authoritarian Rule." Comparative Political Studies 41, no.4 (2008): 715-741. DOI: https://doi.org/10.1177/0010414007313124.

Scott, James C. "Patron-Client Politics and Political Change in Southeast Asia." The American Political Science Review 66 no.1 (1972): 91-113. DOI: 10.2307/1959280.

Stokes, Susan, Thad Dunning, Marcelo Nazareno, and Valeria Brusco. Brokers, Voters, and Clientelism: The Puzzle of Distributive Politics.

Waterschoot, Jessie. "The 2018 Campaign of the Civil Society: Breaking Through the Sectarian System." Heinrich Boll Stiftung Middle East. June 2018. Accessed 1 April 2019. https://lb.boell.org/ en/2018/06/14/2018-campaign-civil-society-breaking-through-sectarian-system. 
Daniel L. Tavana is a Ph.D. candidate in the Department of Politics at Princeton University. Previously, he worked as a research associate at the Project on Middle East Democracy (POMED). Tavana holds degrees from Cambridge University and the Kennedy School of Government at Harvard University, where he worked at the Belfer Center for Science and International Affairs and co-founded the Harvard Journal of Middle Eastern Politics and Policy. His research interests include elections, comparative political behavior, and public opinion in the Middle East and North Africa. Tavana is also a research associate at Lebanon Support.
Christiana Parreira is a Ph.D. candidate in the Department of Political Science at Stanford University. She earned a B.A. in Public and International Affairs from Princeton University in 2013. Her research focuses on how informal institutions and social networks shape local political competition and welfare outcomes, focusing on contemporary Lebanon. She is an affiliated scholar of the Issam Fares Institute at the American University of Beirut, and a research consultant for the Lebanese Center for Policy Studies and Synaps. Parreira is a research associate at Lebanon Support. 